\title{
Effective method of therapy of catarrhal mastitis of sheep
}

\author{
A.Yu. Aliev ${ }^{1}$, B.B. Bulathanov ${ }^{1}$, A.S. Barkova ${ }^{2}$ \\ ${ }^{1}$ Caspian zonal research veterinary Institute branch of "Federal agrarian research center of the \\ Republic of Dagestan" \\ ${ }^{2}$ Ural State Agrarian University \\ Russian Federation \\ Received: May 15, 2020. Revised: June 24, 2020. Accepted: July 1, 2020. Published: July 2, 2020.
}

\begin{abstract}
The aim of the vark was to study of changes in the structure of the mammary gland in vork after treatment of catarrhal mastitis by preparation dioxinor with combined use of oxytocin and novocain blockade according to D.D. Logvinov. The work was carried out in SEC "Gasan" of Dagestan Republic on the ewes of Dagestan rock, in number of 37 heads with catarrhal mastitis. Three sheep for study of pathoanatomical and histological studies were scored before treatment, and three-after treatment.

In sik ewes, a thickening of the mucous membrane of the cistern and large ducts was noted macroscopically, in places with spot-spot hemorrhages, histological studies established dystrophy and necrobiosis of lactocytes, which was accompanied by active desquamation.

In the treatment of catarrhal mastitis with a drug dioxinor in combination with oxytocin and novocaine blockade on the seventh day, with a pathoanatomical study, the structure of the mammary gland was normal, and histological examination revealed the formation of a stable recovery process in the mammary gland, manifested in the purification of the alveoli from the exudate, the restoration of the epithelium.
\end{abstract}

Keywords-Catarral mastitis, ewes, dioxinor, mammary gland.

\section{INTRODUCTION}

CHEEP farming in the Republic of Dagestan is one of the $\checkmark$ developed agricultural sectors and is the main source of income for many peasant farms derived from the sale of wool, meat, and in some mountainous areas -milk processing products.

One economic advantage making sheep farming attractive over other types of farm animals is the ability of sheep to use pasture forage year-round [16].

One of the main reasons of the decline in milk productivity, technological and sanitary properties of milk, premature rejection of ewes, decrease in weight gain, mortality and developmental delay in young animals, as well as the cost of treatment and preventive measures is mastitis. Its spread reaches from two to ten percents. and in some households, it reaches $28.0-31.0 \%$ with a fatal outcome to 14.5 or more percents [1], [2], [8], [20].

According to D. Mura (1957); S. Pissani (1960) on a single study in Italy, mastitis occurs in $15.0 \%$ of surveyed ewes with a fatal outcome of up to $4.4 \%$; B. Rahman et al., (2016) in sheep farms of Iran, the disease is found in up to $16 \%$, in northern Ethiopia mastitis is found in $28.0 \%$ of ewes [9], in farms of the Republic of Nigeria the disease reaches $47 \%$ or more in small cattle ewes [4].

The disease is observed, as a rule, after lambing, reaching its maximum development from May to July months [3], [12], [15], causes huge economic damage to sheep farming due to premature culling of diseased animals, change of livestock due to partial and total loss of dairy productivity, treatment costs, morbidity and mortality of young cattle, quality deterioration of milk and dairy products [13], [18], [19].

Pathologoanatomic investigation of mammary gland lobes affected by mastitis in ewes showed they were hypertrophied, with concretion, had extensive hemorrhagies between lobes and multiple purulent, necrotic and caseose nodules in the parenchyma, and the supercharged lymph nodes were enlarged [10].

Mammary gland histostructure changes in the initial mastitis stages are manifested by the expansion of alveolar ducts and lactiferous sinuses with epithelium concretion. Inflammatory reaction is characterized by stroma edema with the formation of lympho-plasmocytic infiltrates of varying intensity. In alveoli, there is some secretion congestion with admixture of serous exudate, increasing the number of milkstones concretions in alveoli lumen, further developing of the expressed exudative-cell reaction manifested by desquamative catar in alveoli and ducts with serous stroma edema with lymphoid-plasmocytic infiltration. [17].

Domestic science and practice have achieved certain successes in solving the problem of mastitis in sheep, developed and introduced into production methods of the treatment and prevention of mastitis in sheep with the use of antimicrobial agents.

At the same time, despite the achievements, the problem of mastitis in sheep continues to be one of the urgent in science and practice [6]. 
There is no consensus among researchers on mastitis occurrence and spread factors in animals, and pathological and histological changes in sheep mastitis have much in common regardless from microbial agents that the authors consider to be the cause of the disease.

Purpose of work. The study of changes in the structure of the mammary gland in ewes with catarrhal mastitis after treatment with dioxinor.

\section{MATERIAL AND METHODS}

The work was carried out in the SEC "Hasan" of the Kirov region of Makhachkala, $\mathrm{RD}$, on ewes, patients with catarrhal mastitis, in the amount of 37 animals, aged from 4 to 7 years.

Dioxinor was intramuscularly administered to sick animals, twice a day, in dose of $0.1 \mathrm{ml} / \mathrm{kg}$, in combination with intramuscular administration of oxytocin, in dose of 5 units, once a day, in the first two days of treatment and with an elevated novocaine blockade according to D. D. Logvinov $(0.25 \%$ solution of novocaine at a dose of $20 \mathrm{ml}$ into the supramammary space above the affected udder lobe).

The control group of animals $(n=18)$ was treated with the farm accepted treatment method, i.e. intramuscularly injection of bicillin-3 at a dose of 600000 units at an interval of 72 hours, 3 times.

The contents of the mammary gland vas crushed 3-4 times a day in a separate dish and disinfected by boiling.

For the ewes during the experiment conducted daily clinical observations. The treatment results were evaluated on days 3-7 after the last injection of the drug, comprehensively, taking into account their clinical examination, laboratory examination of the secretion from the treated udder lobes and control slaughter of animals bor study of pathological and morphofunctional changes.

Histological studies of breast tissue were performed in accordance with the "Methods of morphological studies" (Voronezh, 2000). The material for histological studies vere breast tissue samples from ewes from patients, catarrhal mastitis $(n=3)$ and after a course of treatment $(n=3)$. Tissue samples were fixed in a $10 \%$ solution of neutral formalin, dehydrated in alcohols, chloroform, embedded in paraffin, sections were prepared, dewaxed, stained with hematoxylineosin and examined by light microscopy.

Physico-chemical indicators of milk samples: fat, protein, density and acidity were determined on the instrument "Lactan". The content of somatic cells was determined using "Somatos-mini", $\mathrm{pH}$ - on the universal ionomer EV-74.

\section{RESEARCH RESULTS}

Mastitis was diagnosed on the basis of clinical signs and the results of bacteriological studies. The symptom complex in sick ewes with catarrhal mastitis was characterized by a depressed state, refusal from feed, high temperature, which reached $41.2^{\circ} \mathrm{C}$ and above, rapid pulse rate and accelerated breathing. The affected half of the udder had a dense consistency, increased in volume, pain was slight, the skin was hyperemic, the secret from the affected lobe was serum-like with an admixture of small flakes and clots. The arterial lymph node is enlarged. On the section, the mammary gland was juicy, contained a pale grayish-yellowish liquid. The mucous membrane of the cistern and large ducts vas thickened, looked rough and reddened, and in some places contaied spotty-point hemorrhages (Fig. 1).

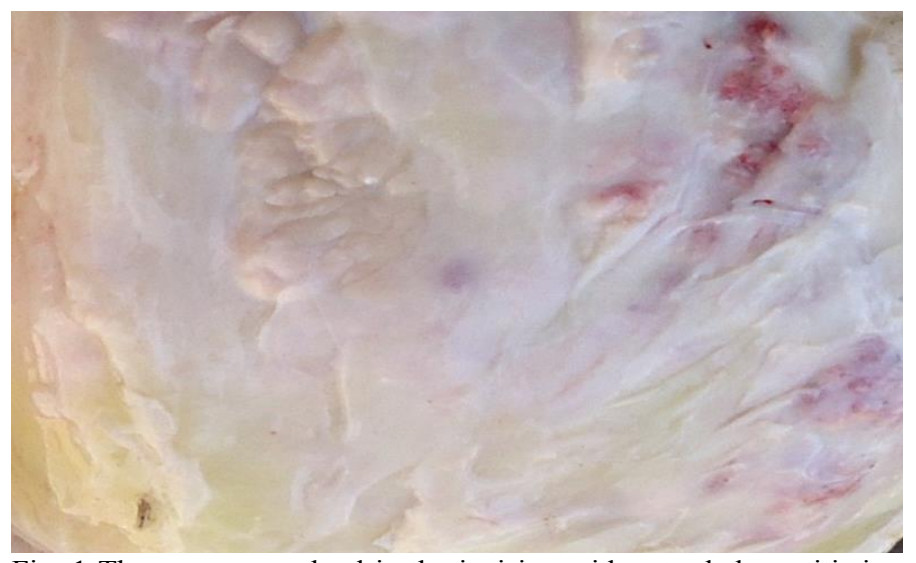

Fig. 1 The mammary gland in the incision with catarrhal mastitis in the ewe with spot-spot hemorrhages on the surface of the incision of the parenchyma. Original.

Our pathological research does not contradict the data of $\mathrm{G}$. Heydrich and V. Renk (1968); N.A. Krasochko, Z.M. Dzhambulatov, K.B. Kurbanmagomedov (2007) who report that in the pathological study of sheep with mastitis, the mammary gland cut is of dark red color, incision surface drains a muddy, grey-red ichorous scent mass. The gland lobes are enlarged, brazen and often dark red. The interstitial tissue is thickened. The alternation of sharply hypermated lobes with lighter areas in the puffiness of interlace connective tissue gives the cut surface a motley color resembling a marble pattern.

Histological studies revealed dystrophy and necrobiosis of lactocytes, accompanied by active desquamation (desquamative catarrh). In the interlobular stroma pronounced edema developed with its swelling, excretion and infiltration by lymphocytes, plasmocytes, and leukocytes. The intralobular stroma of the gland was in a state of edema with massive cellular infiltration, mainly by leukocytes (Fig. 2 and 3).

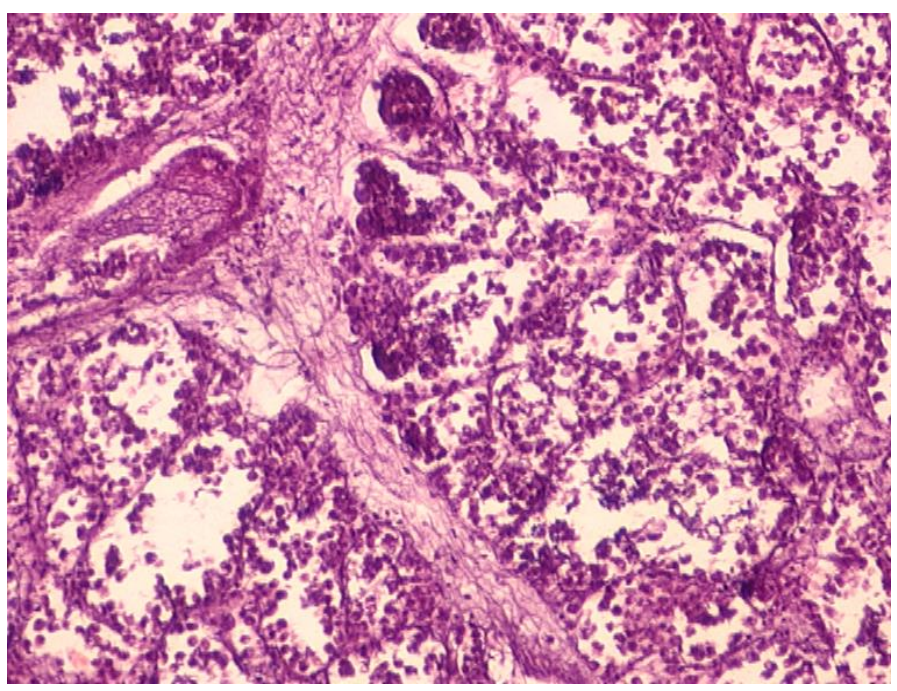




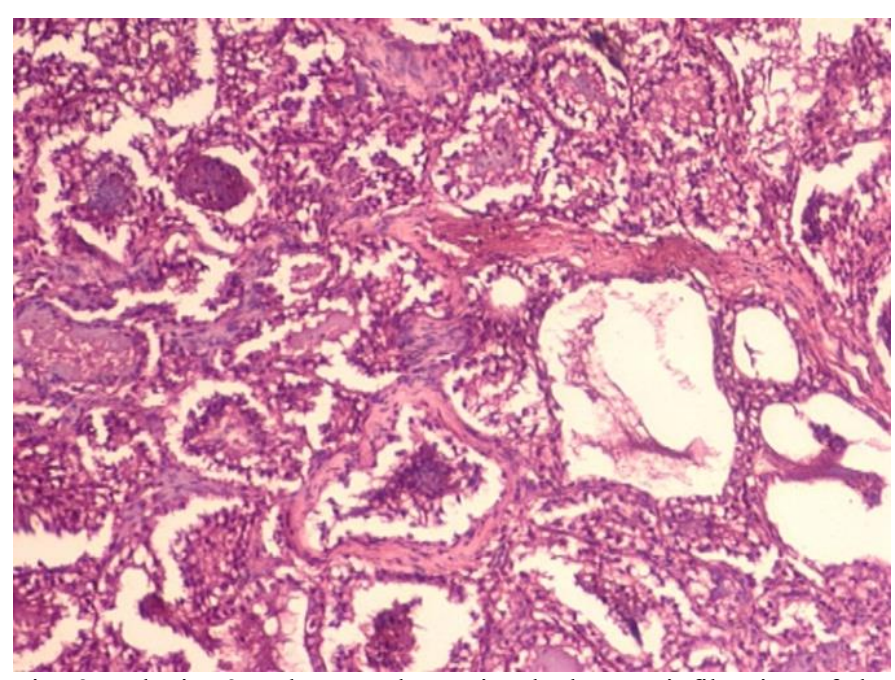

Fig. 2 and Fig. 3. Edema and massive leukocyte infiltration of the intralobular stroma with foci of purulent fusion in the mammary gland in an ewe with catarrhal mastitis. Okr. g. SW OK. 7, about 100.

The structural changes described above were reversible. The use of the complex antimicrobial drug dioxinor in combination with oxytocin and procaine block in the experimental group led to the recovery of sick animals and the restoration of the structural-functional state of ewes' mammary gland. The therapeutic effectiveness of the complex therapy method is shown in the table.

Table 1. Therapeutic effectiveness of dioxinor in combination with oxytocin and novocaine.

\begin{tabular}{|l|c|c|c|c|}
\hline Groups & Treated & \begin{tabular}{c} 
Term of \\
recovery, \\
\cline { 4 - 5 }
\end{tabular} & & \multicolumn{2}{|c|}{ Recovered sheep } \\
\cline { 4 - 5 } & & Quantity & $\%$ \\
\hline Experimental & 19 & $3.5 \pm 0.3$ & 17 & 89.5 \\
\hline Control & 18 & $4.2 \pm 0.1$ & 13 & 72.0 \\
\hline
\end{tabular}

According to the presented data, the developed treatment scheme showed high therapeutic effectiveness in the treatment of ewe patients with cataral mastitis. The recovery time in the experimental group was shorter by 0.7 days compared to the control.

The study results of the physical and chemical milk indicators in the experimental group after treatment are presented in table 2 .

Table 2. Udder secretion indicators in recovered ewes after dioxinor preparation use

\begin{tabular}{|c|c|c|c|c|}
\hline \multirow[t]{2}{*}{$\begin{array}{l}\text { № } \\
\text { it. }\end{array}$} & \multirow[t]{2}{*}{$\begin{array}{l}\text { Milk } \\
\text { Indicators }\end{array}$} & \multirow{2}{*}{$\begin{array}{c}\text { Before } \\
\text { treatment, } \\
(\mathrm{n}=5)\end{array}$} & \multicolumn{2}{|c|}{$\begin{array}{l}\text { After treatment } \\
(\mathrm{n}=5)\end{array}$} \\
\hline & & & Day 3 & Day 7 \\
\hline 1. & $\begin{array}{l}\text { Mass } \\
\text { fraction } \\
\text { of fat, \% }\end{array}$ & $4.5 \pm 0.21$ & $5.7 \pm 0.34$ & $6.8 \pm 0.61$ \\
\hline 2. & $\begin{array}{l}\text { Mass } \\
\text { fraction } \\
\text { of }\end{array}$ & $4.8 \pm 0.12$ & $5.2 \pm 0.11$ & $5.5 \pm 0.13$ \\
\hline
\end{tabular}

\begin{tabular}{|l|l|c|c|c|}
\hline & protein,\% & & & \\
\hline 3. & $\begin{array}{l}\text { Density, } \\
\mathrm{g} / \mathrm{cm}^{3}\end{array}$ & $1.007 \pm 0.2$ & $1.029 \pm 0.02$ & $1.034 \pm 0.02$ \\
\hline 4. & $\begin{array}{l}\text { Acidity, } \\
{ }^{\circ} \mathrm{T}\end{array}$ & $17.7 \pm 0.17$ & $19.5 \pm 1.9$ & $22.0 \pm 1.7$ \\
\hline 5. & $\mathrm{pH}$ & $7.09 \pm 0.7$ & $6.85 \pm 0.5$ & $6.42 \pm 0.5$ \\
\hline 6. & $\begin{array}{l}\mathrm{SC} \\
\text { content, } \\
\text { th/ml }\end{array}$ & $1767.3 \pm 5.01$ & $648.7 \pm 3.1$ & $321.7 \pm 2.8$ \\
\hline
\end{tabular}

According to the data presented, on the third day after the dioxinor treatment end there was an increase of: fat content by $21.0 \%$, protein by $7.7 \%$, acidity by $9.2 \%$; there was a shift in the milk $\mathrm{pH}$ to acid side by 0.24 units, milk density has recovered, somatic cell content was decreased by 2.7 times. A week after the treatment ended, the mass fraction of fat, protein, as well as density, acidity, $\mathrm{pH}$ and somatic cell content corresponded to physiological indicators.

The use of the antimicrobial preparation dioxinor in combination with pathogenetic agents led to the restoration of the structural and functional state of the mammary gland of ewes.

So, on the third day after the course of treatment, against the background of still remaining signs of the exudativeproliferative process, changes in the regenerative- nature were detected in the structure of the mammary gland. In the milky sinuses and alveoli, there was still some expansion and the presence of exudate with an abundant cellular component, lymphoid-plasmacytic infiltration was less pronounced, and the stroma layers looked loosened and fragmented (Fig. 4).

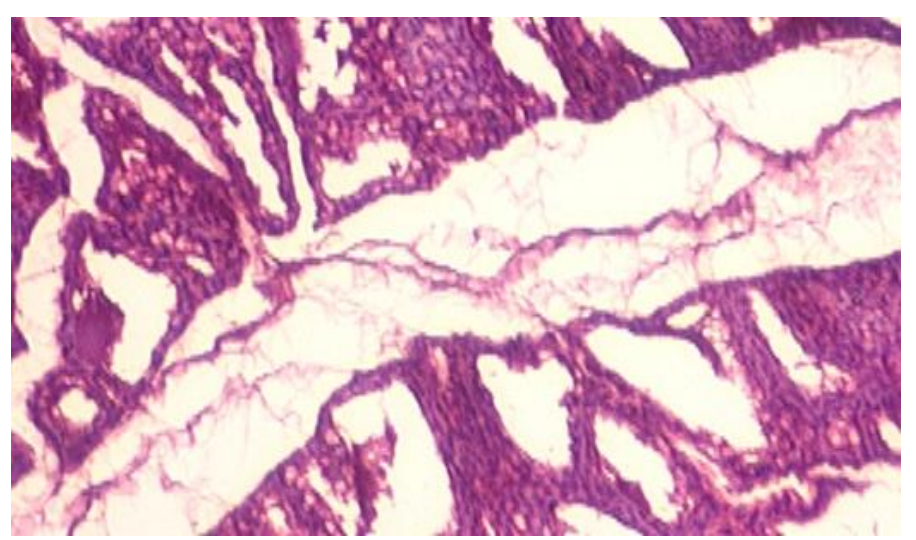

Fig. 4 Interlobular stroma with residual signs of inflammatory edema and excretion. Okr. g. SW OK. 7, about 100.

In the treatment of catarrhal mastitis with a drug dioxinor in combination with oxytocin and novocaine blockade on the seventh day, with a pathoanatomical study, the structure of the mammary gland was normal, and histological examination revealed the formation of a stable recovery process in the mammary gland, manifested in the purification of the alveoli from the exudate, the restoration of the epithelium. 


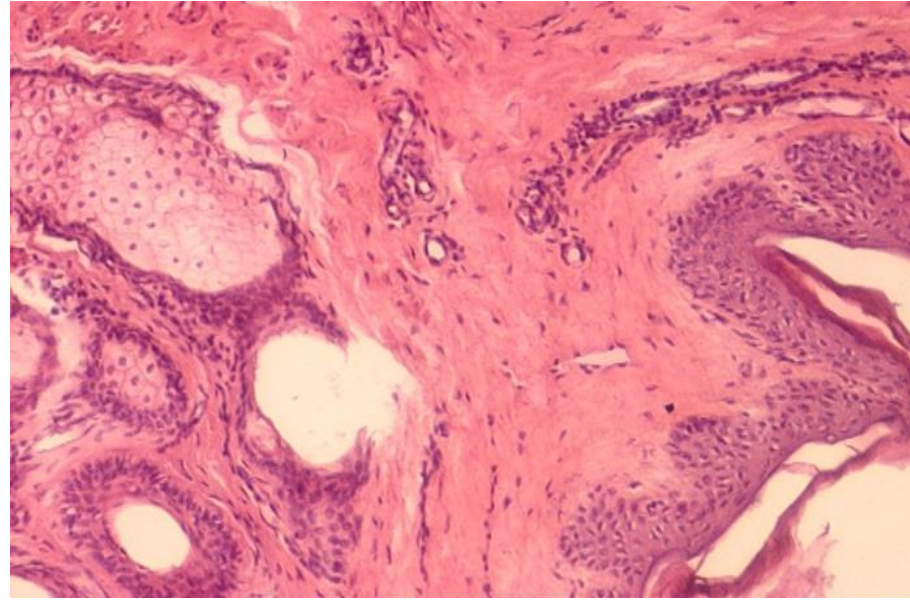

Fig. 5 Nipple region. Minor lymphoplasmocytic infiltration. G.-E. UV.x100.

\section{CONCLUSION}

Thus, the use of dioxinor in combination with oxytocin and novocaine blockade for the treatment of catarrhal mastitis in ewes leads to the purification of alveoli from exudate and restoration of the epithelium, three days after treatment, the inflammatory process in the mammary gland went down, and on the seventh day the milk complied with the physiological norm.

\section{References}

[1] A. Yu. Aliev, Sheep mastitis (diagnosis, etiology and therapy), Author. of dis Dr. of Vet. sciences. St.Petersburg., pp. 44, 2017.

[2] A. Yu. Aliev, M. Z. Magomedov, B. B. Bulatkhanov, Monitoring mastitis in sheep on farms of RD, Veterinary pathology, No. 2, pp. 5-7, 2013.

[3] S. E. Bozhenov, E. N. Grieg, O. E. Grieg, E. E. Grieg, The effectiveness of the use of the drug Aidsidiv for the prevention and treatment of acute mastitis in sheep, Collection of scientific papers. Stavrop. Research Institute of Animal Husbandry and Feed Production. Stavropol, Issue 3. pp. 100-101, 2010.

[4] F. A. Dunmallam, N. V. Pimenov, S. E. Mwannon, I. Libabatu, Bacterial pathogens and risk factors associated with mastitis in small cattle, Bulletin of the International Academy of Agricultural Education, No. 42-2. pp. 180183, 2018.

[5] P. A. Krasochko, Z. M. Dzhambulatov, K. B. Kurbanmagomedov [et al.], Diseases of cattle and sheep, - Makhachkala, pp. 656, 2007.

[6] B. N. Gomboev, I. N. Zyubin, B. Ts. Garmaev, R. Z. Siraziev, Etiology of nonspecific mastitis in ewes, Problems and prospects of increasing of the productive and breeding qualities of farm animals. Materials of the International scientific-practical conference dedicated to the 75th anniversary of the Hero of Socialist Labor, academician of the Russian Academy of Agricultural Sciences, doctor of agricultural sciences, professor V.A. Frost. Stavropol, pp. 5-10, 2012.
[7] G. Heydrich, W. Renck, Mastitis of farm animals and the fight against them, Translation from German, M., pp. $371,1968$.

[8] E. M. Huseynov, Sh. B. Shabanova, K. B. Hasanova, Diagnosis and prevention of latent mastitis, Sheep breeding, No. 2, pp. 37-38, 1993.

[9] T. T. Gebrewahid, B. H. Abera, H. T. Menghistu, Prevalence and Etiology of Subclinical mastitis in small ruminants of Tigray Regional State, North Ethiopia, Veterinary world, Vol. 5, No. 2. pp. 103-109, 2012.

[10] A. Las Heras, L. Domingeuz, I. Lopez, M. J. Paya, L. Pena, F. Mazzucchelli, L. A. Garcia, J. F. FernandezGarayzabal, Intramammary Aspergillus fumigates infection in dairy ewes associated with antibiotic dty therapy, Veter. Rec, Vol. 147, No. 20, pp. 578-580, 2000.

[11] B. Rahman, A. Ownagh, K. Mardani, F. Farrokhi Ardebili, Prevalence and molecular characterization of staphylococci isolated from sheep with subclinical mastitis in West-Azerbaijan province, Iran Vet. Res. Forum, No. 7(2), pp. 155-62, 2016.

[12] M. D. Radjabov, Immunogenic properties of the vaccine against infectious mastitis in sheep, Preventive and therapeutic measures in the conditions of livestock breeding, Tom. 12, Makhachkala, pp. 109-115, 1981.

[13] I. S. Rustamov, New in the treatment of sheep with mastitis, Materials of the Russian scientific and technical. conf., Orenburg, pp. 7-8, 2000.

[14] S. Pisanu, Su di una forma di mastite infettiva e contagiosa delle pecore da Streptococcus zooepidemicus, Vet. ital., Vol. 11, No. 10/11, 1960.

[15] N. A. Sivozhelezova, Obstetric and gynecological examination of sheep and goats, Uch. Allowance, pp. 106, Orenburg 1996.

[16] M. I. Selionova, G. T. Bobrysheva, Z. K. Gadzhiev, S. A. Izmalkov, Sheep economics: pros and cons, Sheep, goats, woolen work, No. 1, pp. 5-9, 2017.

[17] S. M. Suleymanov, O. B. Pavlenko, A. Yu. Aliev, Pathology of the mammary gland in sheep, Innovative development of agrarian science and education: world practice and modern priorities: materials of international scientific and practical. Conf., dedicated to announced in 2015. "Year of Agriculture" in Azerbaijan. Ganja, pp. 362-365, 2015.

[18] M. Tolone, C. Larrondo, M. Yáñez, S. Newman, M. T. Sardina, B. Portolano, Assessment of genetic variation for pathogen-specific mastitis resistance in Valle del Belice dairy sheep. BMC Vet Res. 2016 Jul 28;12 (1): 158 .

[19] L. Omaleki, G. F. Browning, J. L. Allen, P. F. Markham, S. R. Barber, Molecular epidemiology of an outbreak of clinical mastitis in sheep caused by Mannheimia haemolytica, Vet Microbiol, No. 191, pp. 82-7, 2016.

[20] M. Vasil, Aetology of mastitis and enterotoxin production by Staphylococcus sp. Isolated from milk of two sheep herds, Slovak. of animal science, Nitra, Vol. 4. No. 4, pp. 189-195, 2007.

[21] D. Mura, Su di una nuova forma di mastite infettiva e contagic delle pecore causata delle Streptococcus agalactiae, Vet. ital., Vol. 8, No. 5, 1957. 
INTERNATIONAL JOURNAL OF BIOLOGY AND BIOMEDICAL ENGINEERING DOI: 10.46300/91011.2020.14.11

\section{Creative Commons Attribution License 4.0}

(Attribution 4.0 International, CC BY 4.0)

This article is published under the terms of the Creative Commons Attribution License 4.0

https://creativecommons.org/licenses/by/4.0/deed.en_US 